\title{
PHYSICOCHEMICAL CHARACTERIZATION OF LYOPHILIZED BOVINE BONE GRAFTS
}

Carlos Roberto Galia', André Luis Lourenço², Ricardo Rosito ${ }^{3}$, Carlos Alberto Souza Macedo 4 , Lourdes Maria Araujo Quaresma Camargo ${ }^{5}$

\section{ABSTRACT}

Objective: To evaluate the physicochemical characteristics of lyophilized bovine grafts manufactured on a semi-industrial scale (Orthogen; Baumer S/A*) in accordance with a protocol previously developed by the authors. Methods: The lyophilized bovine bone grafts were characterized by means of scanning electron microscopy (SEM), energy dispersive spectroscopy (EDS), X-ray diffractometry (XRD), thermogravimetric (TG) analysis, differential exploratory scanning calorimetry (DSC) and Fourier-transform infrared (FT-IR) spectroscopy. Results: Ca was the main component $(60 \%)$ found in the samples, followed by $\mathrm{P}(28 \%)$ and $\mathrm{O}(5 \%)$. The mean (sd) pore size was $316 \mu \mathrm{m}$ (146.7), ranging from 91.2 to $497.8 \mu \mathrm{m}$, and
$333.5 \mu \mathrm{m}$ (304.8), ranging from 87.2 to $963.9 \mu \mathrm{m}$, at 50x and 150x magnification, respectively. The hydroxyapatite peaks were at $26^{\circ} \mathrm{C}$ and $32^{\circ} \mathrm{C}$, and mass losses were observed between $250^{\circ} \mathrm{C}$ and $640^{\circ} \mathrm{C}$, corresponding to organic material and water. Two temperature transitions $\left(45.67^{\circ} \mathrm{C}\right.$ and $\left.91.89^{\circ} \mathrm{C}\right)$ showed denaturation of type 1 collagen and dehydration of hydroxyapatite. Conclusion: The physicochemical assessment of lyophilized bovine bone grafts in accordance with the protocol developed at semi-industrial scale confirmed that this product presents excellent biocompatibility, with characteristics similar to natural bone.

Keywords - Biocompatible Materials; Bone Transplantation; General Surgery

\section{INTRODUCTION}

The use of bone grafts in orthopedic, cranio-maxillofacial and dental surgery is becoming increasingly widespread $^{(1)}$. Fresh autologous grafts remain the gold standard because of their properties, such as their immune response and osteoinductive, osteoconductive and osteogenic capacities. However, their disadvantages, like the prolonged duration of surgery, small quantity obtained and morbidity associated with this procedure, have limited their use ${ }^{(2,3)}$.

Frozen homologous grafts are also greatly used and are considered to be an excellent alternative, since they avoid the morbidity relating to the donor site.
However, their availability is still very limited within our setting and, albeit rare, there is a possibility of transmission of infectious-contagious and tumoral diseases in relation to their use ${ }^{(4-6)}$.

Hence, alternative biomaterials of natural or synthetic nature and different methods for processing and storing bone tissue have been proposed and exhaustively studied. Among these are bone grafts of bovine origin that have been processed and lyophilized ${ }^{(7)}$. Bovine bone has practically unlimited availability and great physicochemical and structural similarity to human bone ${ }^{(8)}$.

Based on these data, the present authors developed a

1 - Contracted Physician in the Hip Group and Technical Coordinator of the Tissue Bank, HCPA, Porto Alegre, RS; MSc in Surgery from UFRGS, Porto Alegre, RS, Brazil.

2 - Orthopedist and Traumatologist. Resident of Hand Surgery, Hospital das Clínicas de Curitiba, UFPR, Curitiba, PR, Brazil.

3 - Physician in the Hip Group and Tissue Bank, HCPA, Porto Alegre, RS, Brazil.

4 - Adjunct Professor in the Department of Surgery, School of Medicine, UFRGS, and Orthopedics and Traumatology Service, HCPA; Head of the Orthopedics and Traumatology Service, HCPA, and Head of the Hip Group, HCPA, Porto Alegre, RS, Brazil.

5 - Invited Researcher, Tissue Bank, HCPA, Porto Alegre, RS, Brazil.

Work performed at Hospital de Clinicas de Porto Alegre (HCPA), Porto Alegre, RS, Brazil.

Correspondence: André Luis Lourenço - Rua Ramiro Barcelos, 2.350, Bairro Rio Branco - 90035-903 - Porto Alegre, RS - E-mail: alalourenco@ig.com.br

Work received for publication: July 27, 2010; accepted for publication: December 23, 2010.

The authors declare that there was no conflict of interest in conducting this work 
protocol for processing whole-tissue lyophilized bovine medullary bone grafts with the aim of significantly diminishing their antigenicity while only minimally altering their composition in relation to unprocessed bone grafts ${ }^{(9)}$. Natural bone basically consists of an organic matrix of type I collagen containing low molecular weight proteoglycans and non-collagen proteins, corresponding to $25 \%$ of bone weight; a mineral part corresponding to $65 \%$; and water, corresponding to $10 \%^{(10,11)}$. Hence, it is fundamentally important to determine the physicochemical characteristics of the final processed product in order to validate the protocol that was developed.

The objective of this study was to characterize the physicochemical properties of Orthogen whole-tissue lyophilized bovine medullary bone by means of scanning electron microscopy (SEM), energy dispersive spectroscopy (EDS), X-ray diffractometry (XRD), thermogravimetric analysis, differential exploratory calorimetric analysis (DSC) and infrared analysis (FT-IR).

\section{MATERIAL AND METHODS}

\section{Samples}

These were Orthogen samples, and basically the following steps were applied. The raw material was firstly subjected to physical and chemical processes to remove antigenic, bacterial, viral or infectious protein agents. The bones were exposed to successive baths of oxidant agents, organic solvents and alkaline solutions. They were then cut into various formats, lyophilized, packaged and sterilized with gamma radiation.

The tests reported here were conducted at the Analytical Quality Center (CQA) and the Materials Development and Characterization Center (CCDM), of UFSCar and UNESP, and at the Technological Center of PUC/RS, in Porto Alegre.

The following techniques were used to characterize the samples of lyophilized medullary bone grafts under examination: SEM/EDS, XRD, thermogravimetric analysis, DCS and FT-IR.

\section{SEM/EDS Analysis}

Analysis using SEM/EDS made it possible to determine the chemical composition (qualitative and semi-quantitative) on the surface of the sample. The quantities indicated in the EDS microanalysis tables are only semi-quantitative, serving as an indicator of the quantities of each element present, and they cannot be taken to be quantitative analyses. This technique was also used to measure the sizes of the pores of the sample and to calculate their mean size.

\section{X-Ray Diffractometry (XRD)}

This technique consisted of directing an X-ray beam of wavelength 1.5418 Angstroms onto the samples, in order to record the crystalline phases that were present. Through these recordings, the intensities of the diffraction lines corresponding to the phases could be determined, and hence the phases present could be qualitatively determined. The equipment used to characterize the samples was the Siemens Kristaloflex D500 X-ray diffractometer, operating with a cobalt target tube that followed the Bragg-Brentano focusing geometry. The foundation for the procedures was the IT-DRX-220 equipment calibrator, IT-DRX-108 pole figure acquisition system and/or diffractograms ${ }^{(11,12)}$.

\section{Thermogravimetry}

A small quantity of Orthogen was placed in an aluminum sample pan, where its mass was constantly monitored using a thermobalance. The result from the analysis was shown in the form of a graph in which the abscissa showed the temperature or time records and the ordinate showed the residual mass.

The thermogravimetric curve and its derivative in relation to temperature were obtained using a TA 2050 thermal analyzer (TA Instruments). The samples were heated starting from room temperature $\left(23^{\circ} \mathrm{C}\right)$ and going up to $950^{\circ} \mathrm{C}$, at a heating rate of $20^{\circ} \mathrm{C} / \mathrm{min}$, on an aluminum support under a dynamic nitrogen atmosphere (N2), with a gas flow rate of the order of $50 \mathrm{ml} / \mathrm{min}^{(13)}$.

\section{Differential Exploratory Calorimetry (DSC)}

This is a thermoanalytical technique in which the difference in energy supplied to a substance and to a reference material is measured as a function of temperature while the substance and the material are subjected to a controlled temperature program. At thermal transitions presented by the materials, heat is released (exothermic processes) or absorbed (endothermic processes). In this manner, the thermal transitions that different materials exhibit can be studied, 
such as: glass transition temperature ( $\mathrm{Tg}$ ); melting temperature $(\mathrm{Tm})$; crystallization temperature $(\mathrm{Tk})$ and oxidation temperature. DSC curves were obtained using aluminum sample pans with lids. The samples were heated from $-23^{\circ} \mathrm{C}$ to $250^{\circ} \mathrm{C}$, at a heating rate of $5^{\circ} \mathrm{C} / \mathrm{min}$, and the heating was done twice. The experiments were carried out under a dynamic nitrogen atmosphere (N2), at a flow rate of $30 \mathrm{ml} / \mathrm{min}$, using a Mettler Toledo $822^{\mathrm{e}(14)}$.

\section{Infrared Spectroscopy (FT-IR)}

This technique consisted of directing an electromagnetic radiation beam within the infrared band $\left(4000-400 \mathrm{~cm}^{-1}\right)$ onto the sample. Once the energy associated with these wavelengths has been absorbed by the molecules, it is converted into molecular rotation-vibration energy. This absorption phenomenon is extremely quantized and highly dependent on the chemical groupings that are present in the sample, thereby demonstrating their structure. A Nexus 4700 FTIR spectrophotometer (Thermo Nicolet) was used. The spectra were obtained with 32 repetitions, readings from 4000 to $400 \mathrm{~cm}^{-1}$ and resolution of $4 \mathrm{~cm}^{-1}$. A tablet of potassium bromide $(\mathrm{KBr})$ was incorporated with the sample for this analysis ${ }^{(14)}$.

The statistical analysis was done using Student's t test. Values of $\mathrm{p}<0.05$ were taken to be significant, with a $95 \%$ confidence interval.

\section{RESULTS}

\section{SEM/EDS}

The results obtained in relation to chemical composition at random points on the surface of the sample, by means of SEM/EDS, are presented in Table 1. Figure 1 shows images of the sample surface obtained via SEM. The size of the pores is represented in the images of measurements in Figure 2, and the respective results are demonstrated in Table 2.

\section{X-Ray Diffractometry (XRD)}

From the spectrum obtained, the peaks characteristic of hydroxyapatite were seen to be present: the first at around $26^{\circ}$ and the second at $32^{\circ}$, at two times that were designated by reflections (002) and (211), respectively. Figure 3 presents the spectrum obtained for the bone graft sample analyzed.
Table 1 - Chemical composition results obtained by means of EDS.

\begin{tabular}{c|c|c|c}
\hline \multirow{2}{*}{ Elements } & \multicolumn{3}{|c}{ MET 070160 (\%) } \\
\hline $\mathrm{C}$ & Point 1 & Point 2 & Point 3 \\
\hline $\mathrm{Al}$ & 3.94 & 5.01 & 3.71 \\
\hline $\mathrm{P}$ & 0.46 & 0.29 & 0.18 \\
\hline $\mathrm{O}$ & 28.71 & 27.85 & 27.94 \\
\hline $\mathrm{Na}$ & 5.89 & 5.96 & 3.96 \\
\hline $\mathrm{Mg}$ & 0.41 & 0.51 & 0.55 \\
\hline $\mathrm{Cl}$ & 0.75 & 0.49 & 0.50 \\
\hline $\mathrm{Ca}$ & 0.26 & 0.46 & 0.25 \\
\hline
\end{tabular}
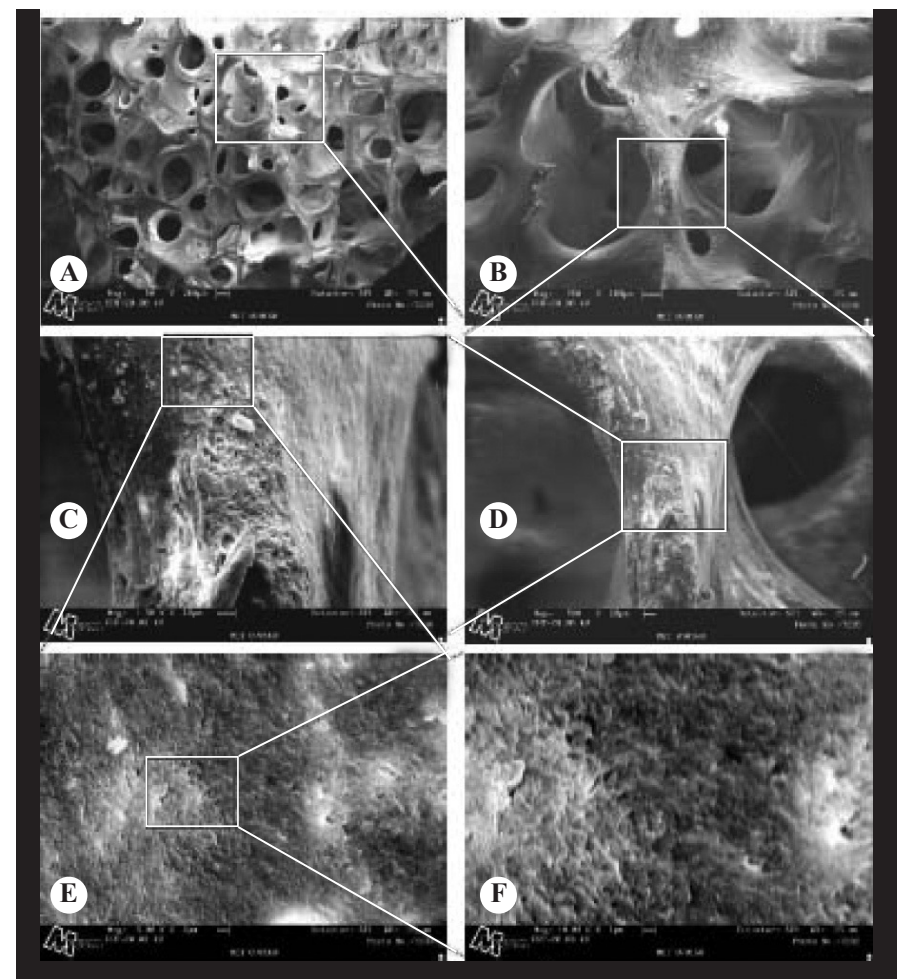

Figure 1- Images obtained via SEM on the surface of the sample: A) magnification of 50x; B) magnification of $150 x$; C) magnification of 500x; D) magnification of 1500x; E) magnification of 5,000x; and F) magnification of 10,000x.

\section{Thermogravimetry}

The results obtained from thermogravimetry on the samples analyzed (Table 3 ) revealed that the losses from the initial mass $(22.8279 \mathrm{mg})$ from room temperature to $250^{\circ} \mathrm{C}$, from $250^{\circ} \mathrm{C}$ to $640^{\circ} \mathrm{C}$ and from $640^{\circ} \mathrm{C}$ to $950^{\circ} \mathrm{C}$ were $8.99 \%, 22.4 \%$ and $6.2 \%$, respectively. This, together with the DSC indicated that there was 


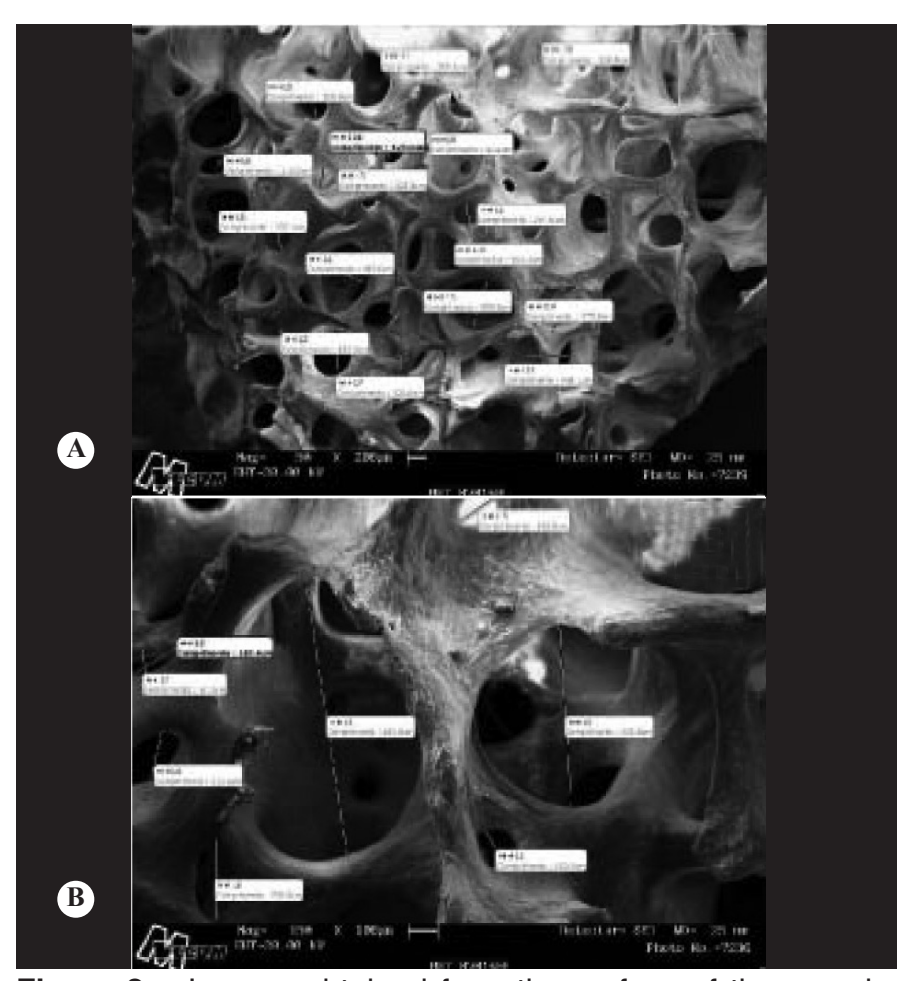

Figure 2 - Images obtained from the surface of the sample, for measuring the pore size: A) magnification of 50x; and B) magnification of $150 x$.

Table 2 - Results relating to pore size.

\begin{tabular}{|c|c|c|}
\hline & Magnification $50 \mathrm{X}$ & Magnification $150 \mathrm{X}$ \\
\hline & \multicolumn{2}{|c|}{ Length $(\mu \mathrm{m})$} \\
\hline L1 & 264.6 & 150.3 \\
\hline L2 & 435.3 & 628.8 \\
\hline L3 & 225.9 & 142.8 \\
\hline L4 & 497.8 & 233.3 \\
\hline L5 & 333.1 & 963.9 \\
\hline L6 & 116.3 & 276.6 \\
\hline L7 & 322.6 & 87.2 \\
\hline L8 & 91.2 & 185.4 \\
\hline L9 & 320.3 & \\
\hline L10 & 136.9 & \\
\hline L11 & 210.1 & \\
\hline L12 & 193.7 & \\
\hline L13 & 458.1 & \\
\hline L14 & 475.9 & \\
\hline L15 & 555.0 & \\
\hline L16 & 429.0 & \\
\hline Mean & 316.6 & 333.5 \\
\hline Standard deviation & 146.7 & 304.8 \\
\hline
\end{tabular}

an initial loss of water from the sample. The level of stable residues at $950^{\circ}$ was $62.6 \%$. The second loss of mass $(22.4 \%)$ probably corresponded to loss of the organic material and structural water. The third loss may have been associated with thermal decomposition of carbonate from the hydroxyapatite (Figure 4).

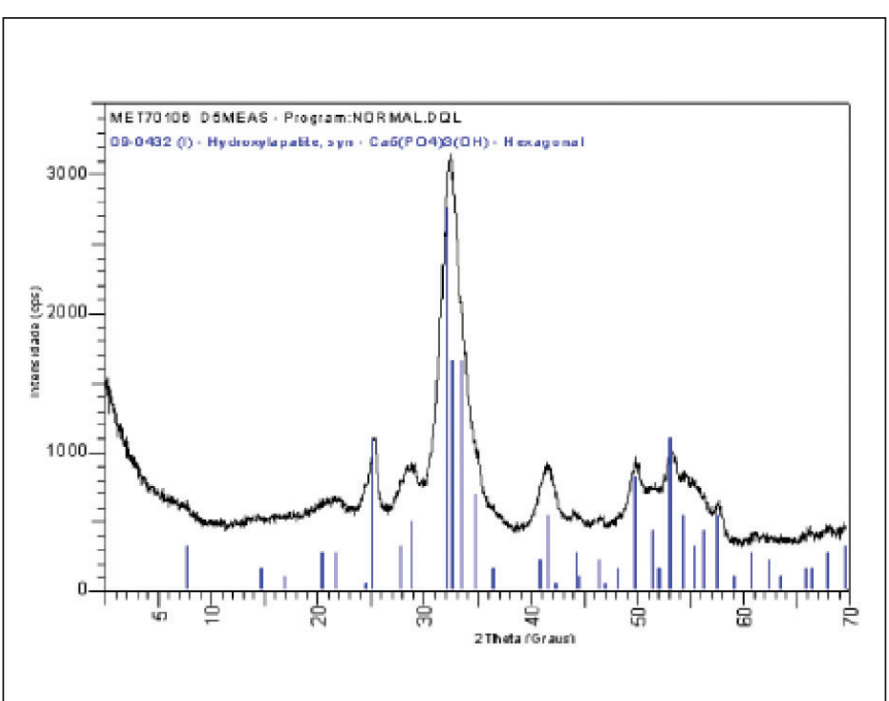

Figure 3 - Curve obtained from the diffraction test.

Table 3 - Summary of thermogravimetry results.

\begin{tabular}{c|c|c|c|c}
\hline Sample & $\begin{array}{c}\text { Loss of } \\
\text { mass }\end{array}$ & $\begin{array}{c}\text { Loss of } \\
\text { mass }\end{array}$ & $\begin{array}{c}\text { Loss of } \\
\text { mass }\end{array}$ & \\
\hline $\begin{array}{c}\text { Between } \\
\text { temperature } \\
\text { and } \\
205^{\circ} \mathrm{C}(\%)\end{array}$ & $\begin{array}{c}\text { Between } \\
205^{\circ} \mathrm{C} \text { and } \\
640^{\circ} \mathrm{C}(\%)\end{array}$ & $\begin{array}{c}\text { Between } \\
640^{\circ} \mathrm{C} \text { and } \\
950^{\circ} \mathrm{C}(\%)\end{array}$ & $\begin{array}{c}\text { Content } \\
\text { of stable } \\
\text { residues at } \\
950^{\circ}\end{array}$ \\
\hline MET070160 & 8.99 & 22.4 & 6.2 & 62.6 \\
\hline
\end{tabular}

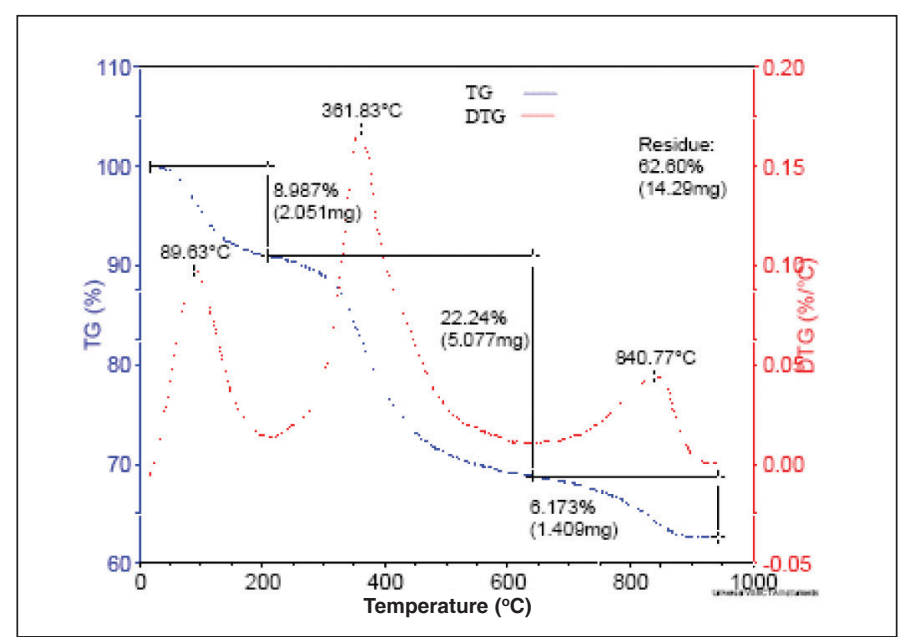

Figure 4 - Curve obtained from the thermogravimetry (TG) analysis. 


\section{Differential Exploratory Calorimetry (DSC)}

DSC curves were obtained both from the first and from the second heating. In the first heating, there were three distinct thermal transitions: at $45.67^{\circ} \mathrm{C}$, $91.89^{\circ} \mathrm{C}$ and $125.89^{\circ} \mathrm{C}$. The first transition temperature observed $\left(45.67^{\circ} \mathrm{C}\right)$ probably corresponded to the denaturing temperature of type I collagen. The major endothermic peak at $91.89^{\circ} \mathrm{C}$ was associated with loss of water from hydroxyapatite, and this was corroborated by the absence of this endothermic peak during the second heating (Figure 5).

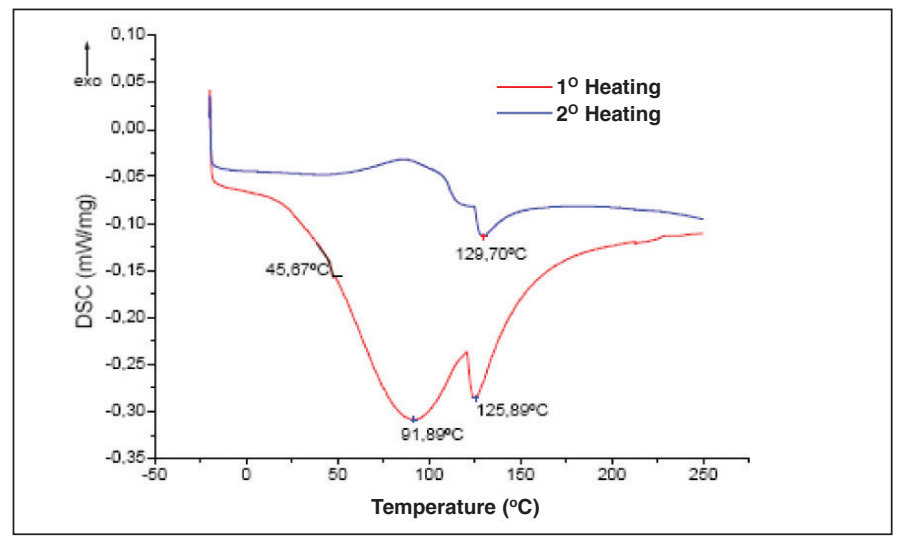

Figure 5 - Curve obtained from DSC.

\section{Infrared Spectroscopy (FT-IR)}

The infrared spectrum of the bone graft sample between $4000 \mathrm{~cm}^{-1}$ and $400 \mathrm{~cm}^{-1}$ is demonstrated in Figure 6, in which the main bands (peaks) observed are indicated.

Characteristic bands were identified for the phosphate groups of the hydroxyapatite (between 600 and 1100), for collagen (axial deformation of the $\mathrm{C}=\mathrm{O}$ chain and angular deformation of the $\mathrm{N}-\mathrm{H}$ and $\mathrm{C}-\mathrm{N}$ chains) and for structural water molecules.

Table 4 presents a description of the bands highlighted and numbered from left to right in Figure 6 . The absorption bands found and presented in Table 4 were as expected for compounds based on collagen and hydroxyapatite.

\section{DISCUSSION}

The microscopic structure of whole-tissue Baumer bone grafts (OrthoGen) was analyzed using SEM/ EDS, and this revealed that the product presented a structure typical of medullary bone, with intercon-
Table 4 - Description of the absorption bands highlighted in Figure 6.

\begin{tabular}{|c|c|c|}
\hline Peak & $\begin{array}{l}\text { Wave number } \\
\quad\left(\mathrm{cm}^{-1}\right)\end{array}$ & Characteristic grouping \\
\hline 1 & 3427 & $\begin{array}{c}\text { Moléculas de água estruturais ou } \\
\text { absorvidas }\end{array}$ \\
\hline 2 & 1654 & Deformação axial da ligação $C=O$ \\
\hline 3 & 1559 & $\begin{array}{c}\text { Deformação angular da ligação N-H e } \\
\text { estiramento C-N }\end{array}$ \\
\hline 4 & 1454 & Ligação C-H do anel pirolidínico \\
\hline 5 & 1243 & $\begin{array}{l}\text { Vibração no plano da amina III, devido ao } \\
\text { estiramento C-N e à deformação N-H }\end{array}$ \\
\hline 6 & 1100 & Íons fosfato \\
\hline 7 & 1037 & Íons fosfato \\
\hline 8 & 872 & Íons $\mathrm{OH}^{-}$da ligação $\mathrm{P}-\mathrm{OH}$ \\
\hline 9 & 564 & Íons fosfato \\
\hline
\end{tabular}

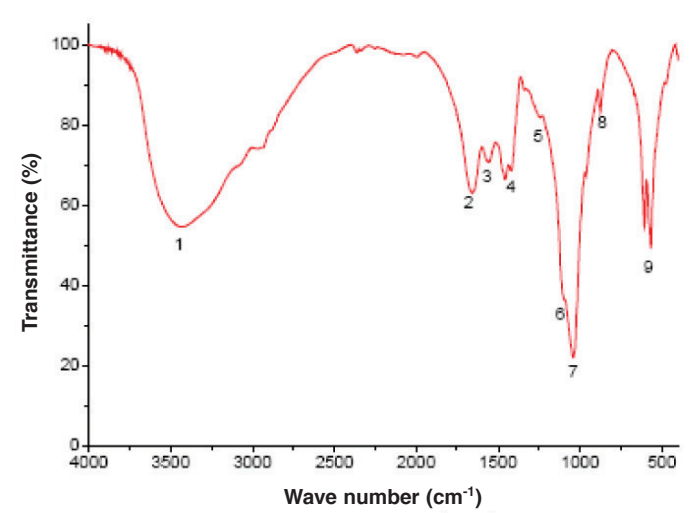

Figure 6 - FT-IR spectrum indicating the main bands observed.

nected pores. Moreover, after the physicochemical process to which the raw material was subjected to manufacture the product, the characteristic structure of this type of tissue could be maintained. Presence of pores and maintenance of the trabeculated crystalline structure of the bone are factors that are fundamental for achieving success in relation to cellular phenomena of deposition of osteoprogenitor cells on the graft, reabsorption of the graft and formation of new bone in its place ${ }^{(15,16)}$.

Some authors have reported the same observations in relation to the microscopic structure, in commercial products subjected to thermal processes of deproteinization, such as BioOss or GenOx $\operatorname{Inorg}^{(10,11,17)}$, or to physicochemical processing not involving high temperatures, such as bovine TutoPlast, Tutobone or human TutoPlast ${ }^{(17)}$, and also in 
non-commercial products subjected to physicochemical processes of cleaning and purification such as $\mathrm{OBM}^{(10)}$ or Kiel bone ${ }^{(17)}$.

Analysis using EDS coupled with SEM made it possible to determine the qualitative and semi-quantitative chemical composition of the surface of the samples. Through EDS, analyzing three different regions on the same sample, it was seen that the material was homogenous. From the result presented, it was observed that the chemical phase of the product was homogenously distributed. The elements aluminum, chlorine and sodium were detected in very low quantities. The elements oxygen and carbon and the minerals $\mathrm{Ca}$ and $\mathrm{P}$ were found at the expected levels for material derived from bone tissue that had not be subjected to a demineralization process. The results obtained were in accordance with those reported by other authors for products derived from bone tissue of human or bovine origin that had not been subjected to demineralization processes ${ }^{(10)}$.

The percentage and size of the pores were determined from analyses on data from SEM. The mean size of the pores was $316 \mu \mathrm{m}(146.7 \mu \mathrm{m})$, ranging from 91.2 to $497.8 \mu \mathrm{m}$, and $333.5 \mu \mathrm{m}(304.8 \mu \mathrm{m})$, ranging from 87.2 to $963.9 \mu \mathrm{m}$, with $50 \mathrm{x}$ and $150 \mathrm{x}$ magnification, respectively (Table 2$)^{(17,18)}$.

$\mathrm{X}$-ray diffraction analysis was used to determine the chemical composition of OrthoGen, and this was indicative of the presence of different phases in the sample, with regard to the purity of the material and the percentage crystallinity ${ }^{(17,19,20)}$. There are several systems that make it possible to determine the peak produced by a given element and to locate it in the test sample, thus producing a map of its distribution. There is a relationship between the width of the peak and the crystallinity of the sample, such that samples that are more crystalline present narrower peaks, while characterization is done according to the locations of the peaks specific for each component.

The spectra obtained from the OrthoGen samples (Figure 3) presented main peals relating to hydroxyapatite. The first was at around $26^{\circ} 2 \theta$ and the second was at $32^{\circ} 2 \theta$, thus denoting that the production process allowed the characteristic mineral phase of the original bone tissue to be maintained, with lower crystallinity, and similar to what is presented by other bone substitutes derived from natural bone that are not subjected to thermal treatment of demineralization during the manufacturing or production process.

In the study conducted by Tadic and Epple ${ }^{(17)}$, several types of bone substitutes of synthetic or natural origin were characterized. With regard to determining the mineral phase, the characteristic peak of hydroxyapatite that is located around $32^{\circ} 2 \theta$ was detected in all the samples studied. It was present, with greater or lesser purity or degree of crystallinity, not only in commercial products of bovine origin (BioOssâ, Endobonâ, Ceraboneâ and bovine Tutoplastâ) or those of human origin (human Tutoplastâ), but also in samples of Kiel bone (bone grafts of bovine origin treated with a mixture of organic solvents and oxidant agents) and in samples of human bone callus or tumoral bone. In relation to the products studied that underwent different manufacturing processes, this information may be used as a means of assessing the efficiency of the processing for maintaining the functional chemical characteristics of the raw material after processing. In determining the crystallinity of the mineral phases by means of X-ray diffraction, for the products Ceraboneâ and Endobonâ, of bovine origin, because these are processed thermally (calcinated) to a high temperature, they present the characteristic of highly crystalline hydroxyapatite. Reabsorption speed has been correlated with the crystallinity of this ceramic, such that the more crystalline it is, the slower the reabsorption will be ${ }^{(10)}$. For the product BioOssâ, an intermediate crystallinity pattern was observed, and for bovine or human TutoPlastâ, the pattern observed was more amorphous or consisted of small-sized crystals, which was denoted by the presence of wider peaks of lower intensity, although still characteristic.

Mendonça ${ }^{(10)}$ evaluated the mineral phase and crystallinity of the commercial products BioOssâ and GenOx Inorgâ, and of samples of OBM, i.e. bovine bone processed with an oxidant agent and denaturing agent, lyophilized and sterilized with gamma radiation, which presents a composition similar to that of human bone: $60-70 \%$ mineral $/ 40-30 \%$ organic and water. For all the products, characteristic peaks of hydroxyapatite were observed at $32^{\circ} 2 \theta$. BioOss and OBM presented wider peaks, which may be associated with the presence of crystals of nanometer 
dimensions, presence of defects in the structure and low post-formation crystallinity. The results presented for OBM were similar to those obtained for the lyophilized bovine bone grafts used in the present study, thus indicating a pattern of much less crystallinity, in relation to patterns presented by products that were subjected to high temperatures during the manufacturing process.

The thermogravimetric profile of the OrthoGen samples was determined. This made it possible to assess the loss or gain of mass presented by the sample as a function of heating, while undergoing a controlled temperature program. This is an essentially quantitative technique, which also presents information on the stability of the material to heat, which can be translated into information on properties like the decomposition of materials of protein and mineral composition.

The initial mass of the sample was $22.8270 \mathrm{mg}$. There was an initial loss of mass of the order of $8.99 \%(2.052 \mathrm{mg})$ between room temperature and $205^{\circ} \mathrm{C}$, which together with the DSC indicated an initial loss of water. A second loss occurred between $205^{\circ} \mathrm{C}$ and $640^{\circ} \mathrm{C}$, equivalent to $22.4 \%$ (5.07 $\mathrm{mg}$ ), which probably corresponded to loss of organic material and residual water. There was a third loss between $640^{\circ} \mathrm{C}$ and the final temperature of $950^{\circ} \mathrm{C}$, equivalent to $6.2 \%(1.04 \mathrm{mg})$ of the initial material, which may have been related to loss of carbonate from the hydroxyapatite. There was a final residue of $62.6 \%$ (14.29 $\mathrm{mg})$, probably consisting of inorganic material that was stable up to $950^{\circ} \mathrm{C}$. These results indicate that the organic and mineral nature of the product was similar to that of the whole bone tissue ${ }^{(12)}$.

Differential exploratory calorimetry (DSC) is one of the thermal analysis techniques used to characterize different types of products with regard to changes caused by heat. Through this technique, it is possible to monitor the variation in energy (difference in energy) between the sample and a reference material, while both of them are heated or cooled in accordance with a controlled temperature program. The character of the peaks (endothermic or exothermic) may vary according to the nature of the phenomenon under examination. Chemical phenomena like oxidative degradation temperature or decomposition tem- perature are important pieces of information when a product with protein in its composition is being characterized. The components present in the sample are identified by comparing the behavior of the peaks found with the reference information for large groups of macromolecules or materials. This is applicable when seeking to identify type I collagen or hydroxyapatite in graft material. The first transition temperature, observed around $45^{\circ} \mathrm{C}$, can be considered to be the denaturation temperature of the type I collagen that was present in the sample. The large endothermic peak observed at $91{ }^{\circ} \mathrm{C}$ was probably associated with loss of water from the hydroxyapatite, and this was corroborated by the absence of this endothermic peak during the second exposure of the sample to heat ${ }^{(10)}$.

Fourier transform infrared spectroscopy (FT-IR) is considered to be the most classical tool for identifying types of chemical bonds. Wavelengths of 40001500 are typically caused by the presence of functional groups known as $-\mathrm{OH}, \mathrm{C}=\mathrm{O}, \mathrm{N}-\mathrm{H}$ and $\mathrm{CH} 3$. In this technique, electromagnetic radiation within the infrared band (waves between 4000 and 400/cm) is directed onto the sample, and the absorption of various infrared wavelengths by the material of interest is measured. The bands of infrared absorption identify specific molecular components and structures. This technique identified bands characteristic for phosphate groupings in hydroxyapatite (from 600 to 1100), for collagen (such as axial deformation of the $\mathrm{C}=\mathrm{O}$ bond, wave 1654; and angular deformation of the $\mathrm{N}-\mathrm{H}$ bond and straining of $\mathrm{C}-\mathrm{N}$, wave 1559) and also for structural or adsorbed water molecules in the sample (wave 3427).

In the study by Tadic and Epple ${ }^{(17)}$, in which several types of grafting material (both commercial and non-commercial) were characterized, the results obtained for bone grafts of partially mineral or partially organic nature, like bovine Tutoplastâ and Kiel bone, were similar to those obtained for the material analyzed in the present study. Groupings corresponding to collagens and organic compounds were found in variable quantities, but with characteristic bands at wave numbers from 1560 to 3000 . In addition to the bands that were characteristic for the phosphate groupings, several bands relating to organic material and incorporated water were observed ${ }^{(17)}$. 


\section{CONCLUSION}

The physicochemical characteristics studied in the lyophilized bovine bone grafts (Orthogen - Baumer) confirmed that this is a product of excellent quality presenting characteristics in accordance with the norms suggested in the literature. Furthermore, it demonstrated similarity with other processed bone grafts that are widely used.

\section{REFERENCES}

1. Finkemeier CG. Bone-grafting and bone-graft substitutes. J Bone Joint Surg Am. 2002;84(3):454-64.

2. Laurencin CT, Khan Y. Bone grafts and bone graft substitutes: a brief history. In: Laurencin CT, editor. Bone graft substitutes. Bridfeport, NJ: ASTM International; 2003.

3. Seiler JG 3rd, Johnson J, Hand G, Microsurgery clinic. Iliac crest autogenous bone grafting: donor site complications. J South Orthop Assoc. [periódico online]. Disponível em: http://www.medscape.com/viewarticle/410431. Acesso em: 11 setembro, 2002.

4. Lind M, Krarup N, Mikkelsen S, Hørlyck E. Exchange impaction allografting for femoral revision hip arthroplasty: results in 87 cases after 3.6 years' follow-up. J Arthroplasty. 2002;17(2):158-64.

5. Palmer SH, Gibbons CL, Athanasou NA. The pathology of bone allograft. J Bone Joint Surg Br. 1999;81(2):333-5.

6. Sugihara S, van Ginkel AD, Jiya TU, van Royen BJ, van Diest PJ, Wuisman PI Histopathology of retrieved allografts of the femoral head. J Bone Joint Surg Br. 1999;81(2):336-41.

7. Giovani AM, Croci AT, Oliveira CR, Filippi RZ, Santos LA, Maragni GG, et al. Comparative study of cryopreserved bone tissue and tissue preserved in a $98 \%$ glycerol solution. Clinics (Sao Paulo). 2006;61(6):565-70.

8. Oliveira RC, Sicca CM, Silva TL, Cestari TM, Oliveira DT, Buzalaf MAR, et al. Efeito da temperatura de desproteinização no preparo de osso cortical bovino microgranular. Avaliação microscópica e bioquímica da resposta celular em subcutâneo de ratos. Revista FOB. 1999;7(1):85-93.

9. Macedo CA, Galia CR, Silva ALB, César PC, Sanches PRS, Duarte LS, et al. Comparação da resistência à compressão do osso bovino congelado e liofilizado. Rev Bras Ortop. 1999;34(9/10):529-34.

10. Mendonça TA. Caracterização físico-química e análise histológica do potencial osteocondutor de diferentes implantes xenogênicos no reparo de defeito ós- seo de tamanho crítico na calvária de ratos (Rattus norvegicus) [dissertação]. Bauru: Faculdade de Odontologia de Bauru, Universidade de São Paulo; 2005

11. Junqueira LC, Carneiro J. Histologia básica. 11a. ed. Rio de Janeiro: Guanabara; 2008.

12. Grynpas MD, Bonar LC, Glimcher MJ. Failure to detect an amorphous calciumphosphate solid phase in bone mineral: a radial distribution function study. Calcif Tissue Int. 1984;36(3):291-301.

13. Jong Jin Lim. Thermogravimetric analysis of human femur bone. J Biol Phys 1975;3:111-29

14. Benz M, Euler WB. Determination of the crystalline phases of poly (vinylidene fluoride) under different preparation conditions using differential scanning calorimetry and infrared spectroscopy. J Appl Polym Sci. 2003;89:1093-100.

15. Werner J, Linner-Krcmar B, Friess W, Greil P. Mechanical properties and in vitro cell compatibility of hydroxyapatite ceramics with graded pore structure. Biomaterials. 2002;23(21):4285-94.

16. Ashok M, Sundaram NM, Kalkura SN. Crystallizations of hydroxyapatite at physiological temperature. Materials Letters. 2002;57(13/14):2066-70.

17. Tadic D, Epple M. A thorough physicochemical characterisation of 14 calcium phosphate-based bone substitution materials in comparison to natural bone. Biomaterials. 2004;25(6):987-94.

18. Tampieri A, Celotti G, Sprio S, Delcogliano A, Franzese S. Porosity-graded hydroxyapatite ceramics to replace natural bone. Biomaterials. 2001;22(11):1365-70.

19. LeGeros RZ, LeGeros JP, Daculsi G, Kijkowska R. Calcium phosphate biomaterials: preparation, properties and biodegradation. In: Wise DL, Trantolo DJ, Altobelli DE, et al. editors. Encyclopedic Handbook of Biomaterials and Bioengineering.. Part A: Materials. New York: Marcel Dekker; 1995. p. 1429-163.

20. Tadic D, Peters F, Epple M. Continuous synthesis of amorphous carbonated apatites. Biomaterials. 2002;23(12):2553-9. 